\title{
Pagode e perigo: rediscutindo contendas de gênero na Bahia'
}

Maycon Lopes

(UFBA)
O movimento antipornografia e seus avatares reclamaram falar por todo o feminismo. Felizmente não falam. (Rubin 1984: 302, tradução minha)

A pornografia e a visão da sexualidade de que ela está imbuída podem significar muitas outras coisas, (...) entre elas a emancipação feminina. A questão, portanto, é que o sentido da pornografia é socialmente indeterminado e aberto. (Silva 2013: 163)

\section{IN(TRO)DUZINDO PELA LEI}

Houve um tempo na Bahia, e não há muito, em que ser feminista significou (ou significa) ser favorável à Lei Antibaixaria ${ }^{2}$ - como ficou nacionalmente conhecido o Projeto de Lei 19.237/2011 -, aprovado pela Assembleia Legislativa do Estado da Bahia no primeiro semestre de 2012, e que

(...) dispõe sobre a proibição do uso de recursos públicos para contratação de artistas que em suas músicas, danças ou coreografias desvalorizem, incentivem a violência ou exponham as mulheres a situação de constrangimento. (Bahia 2011)

Afirmo que não apenas significou como significa porque, se após o decreto da Antibaixaria, em abril de 2012, passamos por um período de relativa quietude na opinião pública no que tange à famigerada lei, os ânimos parecem ter sido revolvidos em agosto do mesmo ano, devido ao lamentável episódio de abuso sexual de duas jovens por integrantes da banda de pagode New Hit, também repercutido em todo o país. Ora, nada surpreendente que parcela significativa das manifestações nas redes sociais tenha remetido o acontecimento à Lei Antibaixaria. Desde as acusações contrárias aos delinquentes - os músicos da banda - àquelas que imputaram culpa às próprias vítimas, as fãs "vadias" (fazendo aqui uma menção ao movimento Marcha das Vadias, sobre o qual me deterei adiante), ambas as 
correntes acusatórias parecem ter encontrado na Lei Antibaixaria um lugar-comum onde puderam repousar, ainda que provisoriamente, seu furor e indignação.

Algumas/alguns daquelas/es que até então não se haviam posicionado com relação à aprovação desta lei, parecem ter sido finalmente convencidas/os de que a proponente da lei, a deputada Luiza Maia, do Partido dos Trabalhadores, e as/os apoiadoras/es do projeto, estavam cobertas/os de razão. Nada como ter uma tese provada. Junta-se ao imaginário popular, que abriga figuras ilustres como a bicha fofoqueira, o judeu avarento, uma nova personagem: o pagodeiro estuprador. Embora, recusando um pensamento mecanicista, eu não atribua o aparecimento da imagem (criminalizada) do pagodeiro estuprador à repercussão da lei, nem considere o abuso sexual produto do pagode baiano, não desprezaria a potência cultural desta lei. Acho pelo menos improvável que aquilo que então denominavam nas redes sociais de "cultura do estupro" , tomando como base produtora e reprodutora de tal ethos todo um gênero musical, emergisse sem que antes tivéssemos sido fecundados pelo debate ocasionado a partir da proposição da Lei Antibaixaria, que fora arbitrariamente fortalecida pelo caso New Hit. Como argumenta a deputada Luiza Maia no portal Fala Ipiaú: “Nós sabemos que quem canta baixaria pratica baixaria, haja visto aquele caso de estupro envolvendo a banda New Hit". Em outra entrevista, desta vez ao portal Bocão News, a parlamentar afirma, referindo-se ao "pagofunk", subgênero do pagode baiano cujo principal representante é Robyssão ("o Mr. Catra baiano"), ex-vocalista da banda Black Style e atualmente líder do Bailão do Robyssão, que:

Com os investimentos em educação, tenho certeza que as pessoas vão aprender a fazer melhores escolhas no tipo de cultura que irão consumir, pois esse lixo cultural é deprimente. Isso vai passar.

Já a estudiosa Cecília Sardenberg (2011), renomada acadêmica feminista e das mais atuantes no ativismo, que, tendo se articulado com a deputada em prol da aprovação da lei, assinala que nas letras do pagode "a imagem da mulher, de todas nós mulheres, é explicitamente aviltada, rebaixada, causando constrangimento naquelas que se prezam".

Outros excertos de entrevistas concedidas pela deputada Luiza Maia a emissoras de rádio e TV merecem também ser destacados. "Imagine as nossas crianças", preocupa-se a deputada em debate no programa Brasil Urgente, da Band, em que expressamente afirma interesse em "resgatar os valores da família". Em outra entrevista (programa Boa Tarde Bahia, da Band), a parlamentar chega bastante longe nas suas interpretações, declarando que a música Me dá patinha ${ }^{4}$ (do grupo Black Style), que fala de uma mulher que se envolvera sexualmente com diversos parceiros, incentiva o estupro coletivo. Nesta mesma entrevista, diz: "Certas danças parecendo que você tá tendo uma relação sexual em público; aí não dá". Ora, como argumentam Clarissa Smith e Feona Atwood a respeito do movimento antipornografia (cujos paradigmas, como se verá, me são muito caros para os fins da crítica que aqui apresento), este movimento tem sido fortemente criticado pela sua, dentre outras fragilidades, "incapacidade de distinguir a sua posição de outras visões altamente conservadoras de sexualidade e gênero" (Smith; Attwood 2014: 10, tradução minha). 
Neste sentido, podemos pensar a parlamentar Luiza Maia como uma empresária moral, ou como uma cruzada moral, reformadora, no sentido que lhe atribui o sociólogo interacionista Howard Becker. Para o autor, os cruzados morais engajam-se na imposição de "sua própria moral às outras pessoas" (Becker 1976 [1966]: 108-9). Entretanto, ressalva Becker, muitos desses reformadores estão imbuídos de forte senso humanitário, e acreditam que se aquelas pessoas, que estão abaixo deles, passem a fazer o que eles consideram correto, isso será bom para elas. Eles podem acreditar, por exemplo, “que sua reforma impedirá certos tipos de exploração de uma pessoa por uma outra" (Becker 1976 [1966]: 109). Tanto Sardenberg quanto Luiza Maia esperam que as outras mulheres passem a se prezar mais, quer dizer, que se autovalorizem, através de comportamento que julgam mais adequado - típica preocupação de empresários morais, os quais, aliás, estão mais preocupados "com fins do que com meios" (Becker 1976 [1966]: 114). Por isso é plenamente aceitável para elas aliar-se a instituições como as igrejas, de interesses não raro conservadores e machistas, a fim de aprovarem um novo marco legal.

Partindo das declarações de Luiza Maia somadas à de Sardenberg, vale pontuar que, ao tomarem como foco a política de representação das mulheres, o sentido de baixaria engendrado pela criação da lei é polissêmico, os quais disponho separadamente apenas para fins heurísticos, pois é certo que eles se combinam e confundem, podendo mesmo ser contraditórios. Baixaria assume, assim, o sentido de: 1) violência a priori; 2) pressuposição de discurso como violência simbólica, que se alia, culmina em, incita, orienta, sustenta e legitima agressões físicas; 3) "lixo cultural" (não arte), a ser combatido com investimento no sistema educativo (implicando, provavelmente, em massificação e qualificação da instrução formal), a fim de que as pessoas, qual a criadora da lei, possam fazer melhores escolhas acerca de produtos culturais que consumirão; 4) aviltamento à dignidade da mulher, ou pelo menos daquelas que têm alguma (dignidade), o que justifica privar as mulheres que não são animadas por este princípio - razão pela qual se submetem ao pagode. Ao fazerem, constrangem "as dignas", uma vez que, enquanto mulher, torno-me representante deste segmento precipitadamente unificado e devo arcar com tal responsabilidade; 5) instituição de uma diferença moral, que não deixa de ser estigmatizante, entre nós, cuja baixaria como forma de entretenimento repudiamos, e elas, pouco comprometidas com o ideal de dignidade da mulher. Ou resistentes a constituir-se enquanto estes sujeitos morais no sentido de Foucault (1984): grosso modo, elaboração ética de si mesmo via conduta moral, moral a que se deve reconhecer e sentir-se obrigado a seguir. Estabelece-se relação com certos preceitos morais e consigo mesmo, a se transformar paulatinamente com vistas ao aprimoramento de si segundo estes preceitos.

\section{ANTECEDENTES: O DESCONFORTO ORQUESTRADO PELA BAIXARIA}

Eu posso, durante um fim de tarde de domingo, passar pela praia do Porto da Barra, observar os conflitos, mas, sobretudo, as coalizões que se formam entre negões, putas e viados. Às alianças que ali ganham vida através da música e que revelam nuances de uma sociabilidade erotizada, bem posso - e muitas vezes o faço - chamar de "baixaria". O Estado pode, e muito mais que eu, a partir do seu olhar exterior e regulador, também aquilo considerar 
uma baixaria. No entanto, a baixaria do Estado é investida de semântica bem diferente da minha, de modo que a sua é pura selvageria e barbárie, predominantemente anticivilizatória; é produto do povo, "que na fala das classes médias sobre hábitos e costumes, é oposto de 'a gente'"' (Sovik 2009: 42).

Já a segunda, a nossa baixaria, bem poderia tomar, despido de todo o investimento moral do Estado sobre o termo, um sentido estritamente topográfico, sobre o qual se estabelece uma gramática alegre - qual a gramática jocosa da Idade Média de que nos fala Bahktin - em que "todas as categorias gramaticais, casos, formas verbais, etc., são transferidos ao plano material e corporal, sobretudo erótico" (Bakhtin 2010 [1965]: 18). É partindo desta premissa que considero a baixaria como o princípio artístico essencial do pagode baiano. Parece-me ainda que aqui, como numa vasta tradição popular da música pautada no "duplo sentido", o riso estabelece relação fundamental com o "baixo" corporal (Bakhtin 2010 [1965]), principalmente com os órgãos genitais.

Neste sentido, o pagode e suas "alusões obscenas" não representam, por assim dizer, uma grande novidade histórica na música popular brasileira, uma vez que aquele gênero em que se acredita tratar de sua própria matriz cultural - a saber, o samba de roda do Recôncavo da Bahia (Moura 1996) - já enlaça letra, música e coreografia em uma espécie de brincadeira picante (Döring 2004). Aliás, se conferirmos os relatos de alguns europeus que vieram para o Brasil nos séculos XVIII e XIX ou que visitaram a Lisboa do século XVIII, podemos observar a conotação dos termos que eles usavam para se referirem a diversas danças aqui/ali encontradas naquele período, como o lundu e a fofa: posições indecorosas, voluptuosidade, insolência, danças lascivas, entre outros. Segundo Tinhorão, a fofa, que fora muito difundida entre os pobres lisboetas, é "a primeira dança documentadamente brasileira e popular" (Tinhorão 1972: 126), tendo estado presente em Lisboa e no Brasil Colônia suburbanos, principalmente entre negros, mestiços e brancos de camadas populares.

Escandalizado, principalmente com a licenciosidade das mulheres, nota o inglês Dalrymple (apud Tinhorão 2008: 64), em viagem a Lisboa em 1774:

A fofa (...) era exibida na farsa por um preto e uma mulher; foi a coisa mais indecente que já vi, e embora parecesse cena de bordel, não parecia incomodar a ninguém; pelo contrário, as mulheres não demonstravam qualquer perturbação, e os homens aplaudiam de pé.

Numa leitura local, pensando no cenário baiano, a baixaria parece se restringir ao pagode. Embora as/os defensoras/es da lei tenham ressaltado que não se tratava de um projeto legislativo contra determinado segmento artístico, e sim contra qualquer música que atente contra a "dignidade da mulher", a maciça maioria dos exemplos citados nas palestras daquelas/es que promoveram a "Campanha Antibaxaria", e veiculados nas diversas mídias eram de músicas pertencentes a esse gênero musical. Acontece que, numa leitura mais ampla, pensando em Brasil, a "baixaria" não se restringe ao pagode. Atualmente atravessa, por exemplo, o funk, o tecnobrega e o forró eletrônico - para citar apenas três gêneros musicais que parecem se valer da baixaria como princípio criativo. Embora não tenha cunhado desta forma, em etnografia realizada nos bailes funk cariocas no final da década de 80, Hermano Vianna observara a presença de uma "carga erótica que perpassa todo o baile" (Vianna 1997: 78) e 
a encenação de "danças altamente eróticas" (Vianna 1997: 93), feitas por grupos de dançarinos compostos em geral só por homens ou apenas por mulheres - dado que, curiosamente, também podemos constatar no contexto do pagode baiano.

Já no final dos anos 90, Jane Souto (1997) observara o processo em curso de alcance e penetração do funk, outrora restrito aos jovens de baixa renda do Rio de Janeiro, no universo das chamadas camadas médias, ou seja, da conquista mais diversificada e ampla do mercado. A autora percebe que as manifestações desfavoráveis ao funk na opinião pública - muitas vezes respaldada pelo próprio Estado através do aparato policial, que, qual a imprensa, o associa ao narcotráfico -, se dão justamente quando o funk deixa de ser um fenômeno restrito aos jovens da favela e passa a ser incorporado por diversos estratos sociais, sobretudo de camadas médias.

"A gente chegou no limite", diz a deputada Luiza Maia em entrevista ao portal Bahia Notícia, na qual claramente se inquieta com a expansão da produção e consumo de músicas de teor erótico na Bahia. Entretanto, seu projeto parece mais ambicioso, uma vez que viajou a diversas localidades, não apenas baianas, em prol da "Campanha Antibaixaria". Em entrevista ao programa Camaçari Tem, da Camaçari TV, a deputada menciona rapidamente a erotização do funk carioca, que também deveria ser coibida. Atualmente, talvez até mesmo pelo fato de a produção e consumo de pagode com este teor não ter estancado, o coletivo antibaixaria está engajado, conforme pude observar em outdoors na cidade de Salvador, em convencer as câmaras municipais das cidades do interior baiano a promulgar esta lei.

O consumo e adesão por diferentes faixas da população nacional e a "ampliação dos espaços públicos autorizados para apresentação de condutas expressões eróticas mediadas pela música" (Rodrigues 2008: 145) acontece concomitantemente, como aponta-nos Rodrigues, à maior adesão das periferias ao mercado de entretenimento. Para o autor:

Essa nova geografia tem como um de seus aspectos fundamentais a transmigração de expressões lúdico-artísticas populares de espaços de apresentação locais, como festas de vizinhança, festas de família, festas de instituições religiosas, casas de meretrício, rodas boêmias relativamente marginais, para espaços de apresentação mais "cosmopolitas", formando um horizonte de visibilidade que atinge grupos humanos que não tinham contato regular com expressões que ficavam confinadas às redes restritas de apresentação dos gestos e da corporeidade. Dentre esses espaços, podemos mencionar as rádios, as casas de shows para grandes públicos, que passam a integrar pessoas de diferentes bairros de uma cidade, as TV's, as redes de comércio informal, que atuam como pólos gravitacionais do consumo de bens simbólicos, divulgando expressões numa escala até então desconhecida. (Rodrigues 2008: 157)

Nesse caldo cultural e circuito de padrões expressivos eróticos que irrompem a partir do consumo de certos gêneros da música contemporânea do Brasil, elenco como arauto a aparição da personagem Jaqueline Carvalho, mais conhecida como "Pró Jack", uma professora de educação infantil que em 2009 repercutiu nacionalmente a partir de um vídeo amador, disponibilizado no YouTube e gravado na apresentação da banda de pagode $O$ Troco.

Quando, ruborizados, para não dizer horrorizados, assistíamos à performance da professora do Todo Enfiado ${ }^{5}$, indagávamos qual repertório cultural - que ainda nos falta - permitir-nos-ia compreender a motivação daquela moça 
que ali se expunha sem maiores pudores, num lugar considerado degradante. Isso faz-me lembrar do expresso choque do viajante inglês ao apreciar a fofa na Lisboa do século XVIII; também ele não compreendia como aquelas mulheres, dançarinas e espectadoras, não se incomodavam com tamanha indecência. Interpelava-se a professora Jaqueline a fim de que ela se comportasse como uma mulher respeitável, habilitada a educar crianças.

Uma interpretação sedutora, mas limitada, nos levava a crer que a "Pró Jack" estava sendo coagida pela misoginia e o machismo, o mesmo machismo que devora qualquer empreendimento e iniciativa pessoal "esclarecidos". Pergunto-me então se o machismo, como essa chave hermenêutica pretensamente universal, responderia a tudo. Ou se, ao contrário, esse modo de interpretar as relações heteroeróticas não limitaria a própria possibilidade de agenciamentos que vazassem tal sistema significante. Trocando em miúdos, certo de que qualquer mulher que "se prestasse" (porque o verbo é esse) àquele papel ultrajante seria considerada alienada, acredito que este modo sempre a priori de ler tais relações impossibilitaria inclusive a tão almejada emancipação feminina, no momento em que a mulher é de antemão suprimida pela leitura como um ser inferiorizado, objetificado e vitimado.

Em um minidocumentário ${ }^{6}$ intitulado Pediu pra parar?, produzido cerca de três anos depois, Jaqueline afirma que, na ocasião em que o polêmico vídeo fora gravado, ela "estava se sentindo à vontade", afirmando em seguida que fora "levada pela emoção", ou seja, havia sido inconsequente; não calculara as implicações de fazer valer naquele momento sua ignóbil vontade. No mesmo curta-metragem, a deputada autora da Lei Antibaixaria argumenta que as mulheres estão habituadas "a se sentir sem valor, a não se prezarem", e que elas "precisam ser conscientizadas". Como pontua a feminista Leticia Sabsay em entrevista à Revista Cult em um dossiê sobre teoria queer, a palavra de Jaqueline Carvalho pode ser:

interpretada como a de um tipo de vítima de Síndrome de Estocolmo, de alguém supostamente incapacitado ou que não conta com a autonomia moral necessária para ser considerado como sujeito de direito no sentido clássico, como alguém que pode falar e atuar por si mesmo. (Sabsay 2014: 40)

Incorre-se no risco então de, ao vitimá-las, desconsiderar a perspectiva das próprias mulheres envolvidas nas relações analisadas (Biroli 2013). Embora não possamos ignorar que formas de opressão e dominação incidam nos processos formativos de preferências eróticas, por exemplo - processos que não são estanques - não podemos supor que aquelas que supostamente se encontram em posição de poder desvantajosa sejam portadoras de alguma espécie de déficit cognitivo, ou, em outras palavras, que a dominação totalize suas experiências (ibid). Se pensarmos que as pagodeiras foram lidas como vítimas de uma Síndrome de Estocolmo, é fácil entender o paternalismo falar mais alto e decretar uma lei que censura e deslegitima certos comportamentos parece dizer “eu, sim, o sei, mas tu não sabes o que é bom para ti. E eu não necessito pedir tua opinião para sabê-lo" (Ogien 2005 [2003]: 159, tradução minha).

Em uma das entrevistas concedidas a programas de televisão pela autora da lei, a ideia da medida surge num pano de fundo de crescente objetificação da mulher. Ora, segundo Martha Nussbaum (1995), dizer que alguém é um objeto para outrem significa apontar um conjunto de características, dentre as quais gostaria de sublinhar: a 
instrumentalidade (o objeto como um meio), a ausência de autonomia (o objeto não escolhe), a inércia (um objeto não pode mover-se por si mesmo), a violabilidade (o objeto não possui fronteiras protetoras), e, finalmente, a ausência de subjetividade (o objeto não tem sensações, emoções, sensibilidade em geral). Por isso fica claro que quando se fala em objetificação da mulher se fala apenas num sentido metafórico. A filósofa ainda argumenta que a objetificação, conceito que reside no coração do feminismo - ou, diria eu, de alguns feminismos - pode representar inclusive uma parte prazerosa da vida sexual, acrescentando que nem todo tipo de objetificação é igualmente objetável, e cita o exemplo do sadomasoquismo, em que a violabilidade dos limites do corpo ancorase em prévio consentimento (garantindo, assim, a autonomia do sujeito).

Dentre as características acima relacionadas para satisfazer à condição de objeto, a mulher - no caso, a emblemática personagem que tem conduzido esta reflexão, a professora do Todo enfiado - parece atender apenas à instrumentalidade: um meio para se chegar ao prazer sexual. Ora, como o vocalista bem o pode ser também para ela, estabelecendo quiçá uma relação de prazer recíproco, embora não seja possível mensurá-lo. Entretanto, o modo como seu prazer é operado, permitindo-se conduzir pelo parceiro, acatando sua proposta, a colocaria irremediavelmente no lugar de subjugada? Não seria este um pensamento essencialmente falocêntrico e, portanto, violento e redutor? Haveria ali, na perspectiva da mulher envolvida, uma situação de violência, ou a cena agride mais especificamente os nossos modelos de erotismo e prazer, em que certas representações são lidas de modo determinista como relações de subjugo e força?

Acredito que, antes de mais nada, precisamos lançar mão de novas leituras, e uma que aqui apenas sugiro é que a "passividade sexual" possa ser também entendida como uma atividade, uma tomada de atitude; que as passivas e os passivos sejam compreendidos como pessoas que desempenham uma ação, mesmo que seja a de permitir-se guiar pela conduta do parceiro. Não intento argumentar que a violência não possa surgir em meio à fruição, à produção do prazer (Gregori 2008), todavia, quem estaria habilitada a avaliar se se sente ou não agredida senão a própria mulher em questão? $\mathrm{O}$ que acontece é que estas mulheres - referindo-me especificamente àquelas que participam dos shows de pagode, que sobem no palco e que parecem sentir-se gratificadas atraindo a atenção do público e da banda - estão desprovidas atualmente de uma posição, um espaço onde possam falar e ser ouvidas, e acabam por ser relegadas, enquanto sujeitos subalternos, à obscuridade (Spivak 2010 [1988]). Mas será mesmo que elas nada nos dizem com as suas performances? Ou nós é que não estaríamos preparados para ouvir o que elas têm a nos dizer? Não estaríamos viciados em sequestrar o que nos falam os seus corpos, imputando violência e agressão às relações tecidas por elas?

É verdade que essas mulheres carregam certo "estigma erótico", e parecem ser alvo de um tipo semelhante de vergonha à que algumas mulheres sentem das prostitutas. Pior: das putas que gostam de ser putas - utilizando aqui tal vocábulo para lembrar com gosto o modo como a saudosa Gabriela Leite, fundadora da ONG Davida - que defende os direitos das prostitutas - dizia preferir ser chamada. As mulheres da periferia que curtem o pagodão (elas não são as únicas) não estão organizadas em coletivos, não possuem representante na Assembleia Legislativa, não estão à frente de nenhuma banda de pagode. Ainda assim há uma ansiedade, um medo por parte de algumas mulheres que esta representação da mulher, pelas pagodeiras supostamente avalizadas, torne-se hegemônica. A Lei Antibaixaria, pois, está também fundamentada na ideia de que o Estado deve limitar o alcance 
destas representações, gerindo as convenções de gênero e sexualidade à baila. Mas quem poderá, e a partir de que parâmetro, dizer qual representação de mulher é legítima e qual é perigosa?

Talvez nos dê importantes lições a esse respeito a Marcha das Vadias ${ }^{7}$, manifestação feminista contemporânea e transnacional, a começar pelo próprio nome com que o movimento fora batizado. As mulheres, ao serem tachadas de "vadias", bem poderiam ter rejeitado o rótulo, e de repente ter contra-atacado pondo em voga um termo mais "respeitável". Mas não: abraçaram ironicamente a injúria e dela fizeram louvor. Somos vadias mesmo, e temos o direito de sermos vadias sem que isso possa implicar na violabilidade dos nossos corpos. Eis a nossa luta. A inteligente sacada do movimento parece embasada no fato de que a negação da "vadia" incorreria no risco de associar dignidade (e cidadania) apenas à mulher "bem comportada", que o é sempre segundo certos parâmetros morais.

Retomando brevemente a questão da voz das mulheres, que, a meu ver, precisa ser revista à luz de uma crítica sobre o logocentrismo ocidental, em que pesem outros modos possíveis de dizer (através do corpo, por exemplo), sobretudo por parte de grupos comumente desempoderados, acredito que ainda precisamos pensar no porquê de não haver na Bahia uma versão local do grupo carioca de funk Gaiola das Popozudas. Em termos de movimento político e política cultural, seria uma alternativa muito mais criativa que o proibicionismo, em geral contraproducente ${ }^{8}$. Ainda assim, não acredito que a questão levantada pela lei seja tão-somente o "por quem é dito", mas "o que é dito", de tal modo que possivelmente haveria semelhante insatisfação e ansiedade social caso a representação lançada pelas próprias mulheres não contemplasse todas. $\mathrm{E}$ todas dificilmente contemplaria. Afinal de contas, a resolução da lei contempla todas?

Em seu texto sobre o debate acerca do movimento estadunidense Antipornografia, cujas similitudes com a Antibaixaria explorarei doravante, argumenta Júlio Silva:

Uma feminista pode sentir-se tomada por sensações (...) de ultraje ao confrontar-se com um filme pornográfico que apresente mulheres como instrumentos de deleite sexual masculino. Entretanto, se levamos a liberdade de expressão a sério, o fato de que uma expressão cause intenso sofrimento emocional e desgosto a uma parte da população ou dane seriamente o amor-próprio de uma pessoa ou de um grupo social inteiro não oferece justificativa para o banimento daquele material nem para o encarceramento dos responsáveis por ele. Do contrário, teríamos que as únicas expressões aceitáveis seriam aquelas que não ferem suscetibilidade alguma, o que, convenhamos, não é uma base muito atrativa para a regulação do debate público, o qual, por sua própria natureza, fere suscetibilidades. (Silva 2013: 155-6)

\section{QUANDO A ANTIBAIXARIA ENCONTRA A ANTIPORNOGRAFIA}

Em diversos aspectos, alguns dos quais já foram por mim elencados anteriormente, o coletivo defensor da Lei Antibaixaria se assemelha ao grupo de feministas antipornografia", que se enquadra no chamado "feminismo radical". Antes de adentrar em outra crítica, recapitulo aqui que ambos os grupos pressupõem que a mulher é tratada como ser inferior destinado a satisfazer os desejos do homem (coisificação - teoria que já critiquei acima), e que, embora de modo sutil, ambos associam a dignidade da mulher a um "não se prestar ao papel de puta". Na verdade, os dois pressupostos se entrelaçam a partir da categoria moral de baixaria, uma vez que ser puta, neste "mapa totalizante da subordinação patriarcal" (Gregori 
2003: 103), significa irremediavelmente estar a serviço do homem. A saída seria justamente não dar para todos, ou não "desrespeitar" (violentar) a mulher nas letras das músicas, de modo que dizer que determinada mulher "dá para qualquer um" seria já uma violência contra ela. É muito tênue aqui a linha divisória entre a ética e a moral. Se existem discursos mais cuidadosos de feministas em defesa da Lei Antibaixaria, existem outros, inclusive da própria autora da lei, que são bastante escorregadios e beiram a moralização da mulher, partindo, evidentemente, de concepções morais particulares e que não poderiam justificar uma decisão pública; uma questão de ética mínima (Ogien 2005).

Segundo nos mostra Silva (2013), citando a feminista mais representativa do Movimento Antipornografia, Catharine MacKinnon, e também Andrea Dworkin, para os fins do projeto lei que proíbe a pornografia, esta significava "subordinação sexual explícita de mulheres" (MacKinnon \& Dworkin apud Silva 2013: 151). Segundo MacKinnon, ainda citada por Silva, "a sexualidade é para o feminismo o que o trabalho é para o marxismo: aquilo que mais nos pertence e o que mais nos é tomado" (MacKinnon apud Silva 2013: 148). Certamente MacKinnon não levou em consideração que:

A política e o sexo estabelecem relações muito mais complexas e contraditórias do que poderíamos pensar. Por exemplo, embora as pessoas possam querer implicar-se a favor de valores como igualdade e reciprocidade em sua vida política, possa ser que não queiram que esses mesmos valores prevaleçam em sua vida sexual. (Halberstam 2008 [1998]: 137; tradução minha).

Há diversas formas, contudo, de prazer recíproco, embora tal reciprocidade nem sempre seja atingida seguindo um mesmo atalho. Silva (2013) discorda da tese de que o vetor principal de desigualdade entre homens e mulheres seja a pornografia, e também de que o epicentro da identidade feminina seja necessariamente a sexualidade, o que me recorda Merleau-Ponty (2006 [1945]) ao falar do corpo sexuado na sua Fenomenologia da Percepção. Para o filósofo, o avanço da teoria freudiana consiste menos na consideração da sexualidade como uma infraestrutura, e mais na reintegração desta operada pela psicanálise, que, antes concebida como que circunscrita, um ciclo autônomo, passa a ter lugar no movimento de toda existência.

Outro ponto em comum entre os coletivos feministas antibaixaria e o antipornografia é que ambos parecem repousar sobre o pressuposto de que o consumo de produtos culturais com determinado conteúdo pode ter um efeito criminógeno. Pode estimular, por exemplo, agressão física contra mulher ou abuso sexual; argumentos consequencialistas aos quais também se opõe Silva (2013), pois tratam-se de vínculos difíceis de serem estabelecidos. Vem daí a possibilidade de se falar em "cultura de estupro", pensando a cultura como um repertório de práticas, valores e normas. Para Gayle Rubin "o discurso feminista antipornografia se encaixa perfeitamente na tradição de justificar tentativas de controle moral reivindicando que tais ações protegerão as mulheres e crianças da violência" (Rubin 1984: 317, tradução minha).

Esta é a chamada teoria do dominó; a criança que joga videojogos que exploram a temática da violência e depois deseja tomar uma arma para si e atirar nos coleguinhas. Perceba que essa teoria é uma teoria sem sujeito. $O$ sujeito desaparece na medida em que desaparece mundo - uma diversidade de contextos e referências a partir das quais a pessoa, a um só tempo, é posicionada e posiciona-se. Ora, a comunicação não é produto de uma entidade sistêmica sem sujeitos; pelo contrário, exige a presença de um interlocutor (Callejo 2001). E esse interlocutor, que é receptor da 
mensagem, não é um receptor passivo; a comunicação é uma relação de intercâmbio no qual também o receptor produz sentido, ou "não é eficaz se não inclui também interações de colaborações e transação" (Canclini 2006 [1995]: 60) entre emissor e receptor.

Assim como não é necessário ser exposto à pornografia para violar ou agredir uma mulher (Ogien 2005), também não é necessário ser consumidor de pagode e de letras que supostamente estimulariam a violência contra a mulher para abusá-la sexualmente ou agredi-la. Do mesmo modo que não está claro que a Lei Antibaixaria em vigor contribuirá consideravelmente para reduzir a violência contra a mulher. De forma análoga à teoria do dominó, é pressuposta a teoria da "lavagem cerebral", com base na qual, como ressaltei anteriormente, torna-se cabível (e desejável) uma postura paternalista por parte do Estado. A teoria da "lavagem cerebral" é aplicada no pagode baiano quando uma mulher se deleita desempenhando um papel politicamente inaceitável, que ninguém em "sã consciência" se prestaria.

Indago então se sentir prazer com músicas que teoricamente escracham a mulher seria apenas a erotização masoquista da sua dominação. É quando, pensando intuitivamente a partir da minha sensibilidade subalterna, posicionome lado a lado de Giancarlo Cornejo (2011). Na sua belíssima autoetnografia La guerra declarada contra el niño afeminado, ele revela que, durante a infância, seus colegas de escola costumavam passar a mão na sua bunda. Em certo momento ele percebeu que aquela experiência que primeiramente lhe provocava dor fora convertida numa experiência de vergonha, embora acompanhada por gozo e prazer, de tal modo que aquelas "metidas de mão" já significavam carícia. Assim, os seus colegas de escola eram forçados a reconhecer seu próprio fracasso em humilhá-lo. Pergunto-me se é possível entender o prazer nessas relações como submissão. Para mim, sentir prazer com o que seria considerado homofóbico, é desmontar a própria homofobia, fazendo com que os agressores não sejam exitosos em seu projeto. A violência não se concretiza sem vitimar alguém. $O$ prazer neste caso é resistência.

Por outro lado, não quero aqui considerar que certas músicas são feitas na intenção de machucar ou violentar a mulher. O problema é que quando elas são lidas como músicas que fazem das mulheres submissas e quando algumas mulheres de fato acatam a proposta da música, essas mulheres são ainda tidas como alienadas, dominadas, submissas (passivas), ou seja, como despossuídas de agência. Minha crítica aqui caminha na mesma direção daquela em que descarto a leitura da suposta passividade como uma não ação ou uma não agência.

Ao estudar um movimento de mulheres islâmicas, Saba Mahmood (2004) se opõe a esse tipo de pensamento, considerando, em consonância com Lila Abu-Lughod, que se ocupar em identificar certos atos como "resistência" pode ser um projeto bastante problemático. Vou explicar. Partindo da premissa liberal e progressista de universalidade do desejo de "liberdade", passou-se a considerar a agência das mulheres apenas em situações nas quais elas apresentavam resistência às relações de dominação. Essa naturalização da liberdade como ideal social faz com que atitudes e movimentos que não correspondam a este ideal sejam entendidos simplesmente como internalização das normas patriarcais. É neste contexto que surge o desconforto de Mahmood, que advoga que a liberdade acaba por ser normativa para o feminismo, como o é para o liberalismo. As mulheres que não cumprem valores e normas predeterminadas que caracterizam o ideal de autonomia, não são vistas como livres. 
Para a autora é urgente a separação do conceito de agência das metas de política progressistas. Por estarmos ainda fortemente embasados nestas noções, que implícita ou explicitamente equipara agência a resistência à norma, não conseguimos compreender sem sermos simplistas o porquê da professora Jack ter-se exposto naquele espetáculo da banda $O$ Troco. Parafraseando Mahmood, pergunto-me como é que vamos analisar a construção de diferentes tipos de saberes, corporeidades e subjetividades que não podem ser encapsuladas pelas diretrizes políticas libertárias. Ora, a agência existe em diversas modalidades, e não apenas na contra-hegemônica. Neste sentido, o interesse da reflexão de Mahmood não é apenas como a norma é consolidada e/ou subvertida, mas como ela é realizada, vivida, habitada, aspirada, alcançada, consumada e experimentada em uma diversidade de maneiras.

\section{ESTUDANDO O PAGODE}

Alguns estudos empreendidos recentemente sobre o pagode baiano e as relações de gênero nele envolvidas têm produzido resultados bastante questionáveis, tendo como partida um problema para o qual já possuem uma resposta de antemão. Esses estudos pretendem compreender como as mulheres contribuem, a partir da "adesão" à música, ou da sua corporificação, para a manutenção da sua própria desigualdade (perante os homens). Sendo assim, em vez de abrir a possibilidade da negação da sua hipótese, de dominação masculina, ou pelo menos a possibilidade de sua complicação, parecem mais engajados em reificá-la, sustentando seus argumentos na rígida dicotomia dominação/ emancipação. Fazem-no a qualquer custo, mesmo quando os atores, ou melhor, as atrizes a quem apenas supostamente ouvem sugerem o contrário. Dão-lhes voz para em seguida sequestrá-la.

Para estudiosos como Bruno Latour (2007 [2004]), a cuja concepção me filio, isso consiste em um problema, pois, seguindo os passos de Isabelle Stengers e Vinciane Despret, ele afirma que uma ciência bem articulada, interessante, não é aquela ungida de preconceitos, resultado de um frio distanciamento entre pesquisador e pesquisado, mas, isto sim, aquela que possa oferecer ocasiões para o fenômeno estudado objetar a tais pressuposições. Assim, boa distância, a que devemos ter em conta, é a distância que se observa entre o início e o fim da pesquisa. Devemos, então, nos perguntar: será que temos agora um novo repertório de ações? "Se sim", argumenta Latour, "não foi tempo perdido; se não, gastou-se dinheiro em vão, e não interessa quão 'científicos', no sentido tradicional, pareçam os resultados" (Latour 2007 [2004]: 52).

Na dissertação de Anderson Pena a respeito das letras de algumas canções que tematizam o interesse econômico da mulher na relação afetivo-sexual e da sua contestação com a opinião de entrevistadas/os, que corroboram com tal representação, o autor surpreende-se com a visão que as próprias mulheres têm delas mesmas, dizendo que "até as mulheres compartilham da visão que concebe a mulher como interesseira" (Pena 2010: 95). Mais adiante, baseado em entrevistas realizadas com moradoras de alguns bairros da periferia de Salvador, o autor expõe:

Questionadas se essa atitude não causa uma relação de dependência com respeito aos homens, houve unanimidade em discordarem, uma delas explicando: "não vejo nada disso, eu só penso que muitos só tão a fim de curtir com a gente mesmo, sem compromisso, então a gente também curte eles, o carro, as farras, afinal merecemos conforto. (Pena 2010: 95) 
O que aparentemente, sustentando-se em um monismo explicativo, que considera a relação econômica como a mais importante e determinante, indicaria uma relação de dependência entre a mulher e o homem, na verdade mostra como essas mulheres se valem, de modo pré-reflexivo ou estrategicamente, a relação de troca entre o seu capital erótico - grosso modo, habilidade em seduzir e satisfazer seu parceiro sexual - e o capital econômico dele. Se não poderíamos considerar exatamente subversiva a prática dessas mulheres, tampouco poderíamos considerá-las rigidamente subordinadas aos homens com os quais se envolvem.

Hakim (2010), teórica responsável pela sistematização do postulado do capital erótico, comenta estudos que demonstram como algumas mulheres têm ascendido socialmente através desta forma específica de capital. Ela argumenta que é inconveniente para as feministas admitirem que muitas mulheres servem-se do que para as primeiras é instrumento de sua própria opressão, a atratividade física, como poder de barganha na vida social. Prova disso é a atribuição da qualidade de vítima àquelas que trabalham no mercado do sexo, o que acaba, de certa forma, por reafirmar o pensamento masculinista que diagnostica falta de inteligência naquelas mulheres que desfilam sua beleza. Tais concepções iluministas asseguram autoridade da razão através de "uma necessária exclusão de tudo o que é corporal" (Mahmood 2004: 13, tradução minha). O capital erótico para Hakim é um importante trunfo para grupos que têm menos acesso aos capitais econômico e social, como jovens e adolescentes, minorias étnicas, classes trabalhadoras, etc. Também Leme (2003) fortalece esta perspectiva, defendendo que o corpo (através do atletismo e da dança, por exemplo) tem sido um meio importante para conquistar riqueza, prestígio e inserção social.

A epígrafe do texto "Por amor ou por dinheiro? Emoções, discursos, mercados", de Miriam Adelman (2011), sintetiza este incômodo, quando uma escritora moçambicana pontua que:

O mundo acha que as mulheres são interesseiras. E os homens não são? Todo o homem exige da mulher um atributo fundamental: a beleza. As mulheres exigem dos homens outro atributo: o dinheiro. Qual é a diferença? Só os homens podem exigir e as mulheres não? (Chiziane apud Adelman 2011: 118)

No artigo, Adelman posiciona-se contra essa linha de pensamento, tão presente tanto no senso comum como na moderna teoria social, que polariza economia e afetividade, e nos lembra, através da antropologia das emoções de Claudia Rezende, que discursos emotivos não se alheiam, mas são peças nos jogos de relações sociais e de negociações de poder.

Embora o pesquisador Anderson Pena não deixe de focar as letras das músicas como instrumento privilegiado para pensar as relações de gênero estabelecidas no e pelo pagode baiano, como o faz também outros trabalhos (Nascimento 2012b), seus informantes observam que os ritmos e as coreografias preponderam em relação às letras. A meu ver, isso sugere inclusive uma incapacidade de compreender o próprio processo de consumo do pagode que é pressuposto pela Lei Antibaixaria, que, no decreto sancionado pelo então governador da Bahia, reduz a música à letra.

Quando observa as coreografias nos shows, que narra, no seu viés monolítico, como completa dominação masculina e submissão das mulheres, passando por rotulações por parte deles em referência a elas e exibições delas para eles, Pena, sem maiores evidências empíricas, conclui que "tudo isso direciona para a violência, admitindo-se até as agressões físicas contra mulheres" (Pena 2010: 97). Em outro momento da sua dissertação, Pena adverte que a música 
Me dá patinha, da banda Black Style, retrata a ampla banalização da mulher, sendo que banalizar aqui é ter múltiplos parceiros sexuais. Para ele, comparar a mulher a um animal no cio trata-se de uma "estratégia de completa fragmentação do corpo feminino, para então desqualificá-lo e justificar até mesmo a violência física" (Pena 2010: 100). Em seguida, a fim de sustentar o seu argumento, ele expõe a letra de uma música que tem como um dos versos "ela gosta de tomar pancadinha". Segundo Pena, a descrição de tal prática sexual, assim como o jogo de interação erótica que se desenrola nas performances do pagode, bastaria para confirmar o projeto deste gênero musical de legitimar a violência contra a mulher. São interpretações perigosas; em primeiro lugar porque se trata de uma leitura descolada do ambiente em que a canção é consumida, descolada da própria música, que incita a dança e o erotismo, e, em segundo lugar, por ser uma interpretação que carrega consigo um tom prescritivo: o modo correto de sentir prazer.

Trata-se de uma agenda de cima para baixo, tipicamente violenta (Hakim 2010), como o é a Lei Antibaixaria, cuja campanha apresentara um cartaz (abaixo) grafado "Batidão sim, contra a mulher não", sobre uma imagem em que a mulher, com "bunda empinada", parece aguardar um "tapinha" do seu parceiro. O cartaz faz uma alerta à sociedade: que o (ali colocado como) "agressor" não deve praticar violência contra a mulher, a qual parece não saber que está sendo violentada (mas que nós bem sabemos que está). Para algumas feministas, este tipo de representação de entretenimento e prazer sexual, a que imputam incitação - de difícil comprovação - a ódio e violência, não deve ser tolerada pelo Estado.

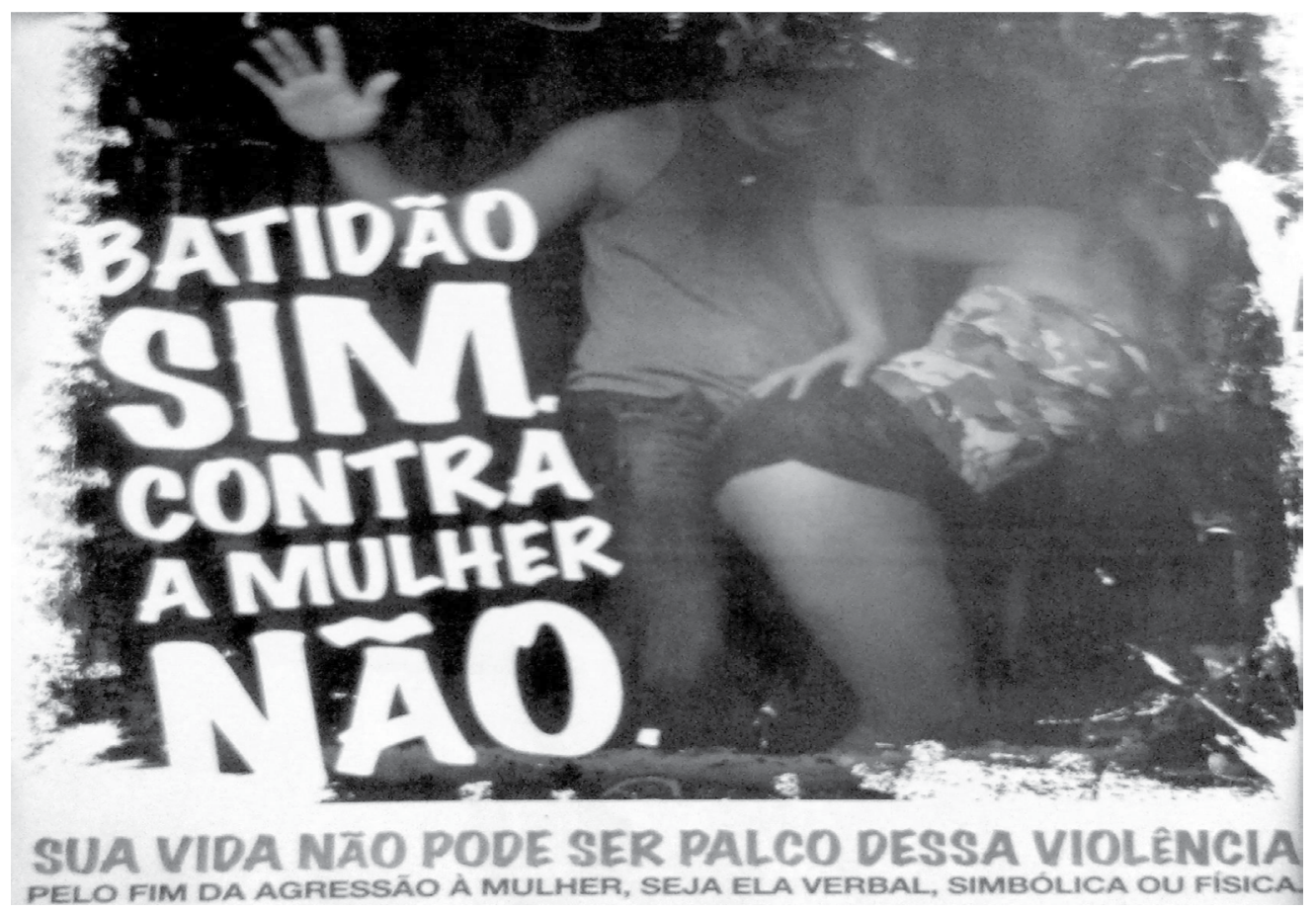


Ainda no trabalho de Pena, ao questionar uma moradora do Nordeste de Amaralina acerca da música Tapa na cara, ela argumenta:

Tem mulher que gosta de apanhar mesmo, mas apanhar como diz a música antiga que Chela do "Pagodart" canta: "Tapa na cara". Acho que as letras do pagode falam em bater nesse sentido, mas não como agredir ou matar a mulher. Então é o prazer na hora do "balacobaco", que tem muitas mulheres que gostam e até pedem mesmo para o cara bater nelas na hora " $\mathrm{H}$ ", mas não vejo muita maldade nisso, acho apenas que brinca com uma coisa que é verdade mesmo. (Pena 2010: 106-7)

No texto que segue, o autor afirma: "como vimos, os seguidores do pagode não admitem que as 'pancadinhas' representam violência física" (Pena 2010: 106). Enfim, esse estudo reivindica uma leitura exclusivista das letras das músicas do pagode com o intuito de atestar a relação entre o pagode e "seus seguidores" e violência de gênero, mesmo quando as respostas de suas entrevistadas desafiam tal pressuposto. Em verdade, é difícil compreender a razão pela qual Anderson Pena optou pelas entrevistas na metodologia do seu projeto, uma vez que sua conclusão ignora os dados nelas produzidos, ou as próprias atrizes investigadas, e, numa multivocalidade fictícia, confere valor apenas ao estudo de representação levado a cabo pelo próprio pesquisador.

O autor assume posicionamento muito próximo ao da deputada Luiza Maia, que em debate no programa Que venha o povo, da TV Aratu (afiliada ao $S B T$ ), afirma que a música Tapa na cara estimula a violência. Conforme pontua McNair (2014) acerca da literatura antipornografia - argumento de que podemos nos apropriar para ponderarmos os estudos sobre o pagode - esses trabalhos têm ignorado o contexto e ambientação de sua lírica, sobretudo quando estas "representam formas de violência sexualizada, (...) em favor de uma leitura literal de seu conteúdo" (ibid: 162, tradução minha).

Já Clebemilton Nascimento (2012b), numa oficina de letras de músicas, colheu a seguinte afirmação, oriunda de uma participante: "Eu gosto de pagode, não sei... por mais que eu tenha consciência da pobreza musical e da vulgaridade das letras, eu danço swingueira; é algo que me leva, que balança, que me envolve" (Nascimento 2012b: 100). O pesquisador infere que há na fala da informante "um reconhecimento implícito ao tratamento assimétrico dispensado às mulheres nas letras, quando afirma estar 'consciente' de que a música parece vulgar, sinônimo de (des)qualificadora" (Nascimento 2012b: 101). Ora, não há nenhuma referência clara no discurso de sua colaboradora que nos leve a crer numa consciência da desigualdade de gênero produzida pela letra da música do pagodão. Pelo contrário, tal qual nos relatos do trabalho de Pena, o que é sugerido é que o pagode fala e envolve mais pelo ritmo - que convida o corpo a com ele mover-se - do que pela letra, que parece secundária no consumo da música, mas que recebe atenção primaz tanto dos pesquisadores citados quanto das feministas defensoras da Lei Antibaixaria.

Nascimento cumpre o objetivo de, a partir de uma interpretação de antemão fixada, compreender as representações de gênero à baila no pagode, mas não consegue responder como o espaço do pagode, que para ele é "hostil às mulheres" (Nascimento 2012b: 128) exerce atração sobre elas. Em certo momento o autor esclarece que, em detrimento das letras, as músicas as contagiam através do ritmo e "as faz encenar sua própria 
desqualificação" (Nascimento 2012b: 107). Aqui me parece que a metáfora ideal é da abdução: a mulher que tem sua consciência usurpada pelo ritmo e que por isso não consegue perceber o quanto aquilo que faz é degradante. Patrulha-se novamente em favor de uma preestabelecida representação ideal de mulher.

Quando o autor analisa a performance de Todo enfiado, ele dicotomiza a posição da mulher numa fórmula bastante simplista e que já critiquei acima, entre dominada e autônoma, e escolhe, evidentemente, a primeira. Em entrevista concedida à EDUFBA, reforça o mesmo binômio, ao indagar se "a desqualificação não é uma reiteração da norma ou [se] elas, as piriguetes, estão subvertendo o modelo idealizado da mulher de verdade?" (Nascimento 2012a). Cambiante entre estes dois polos, considero improvável que esta aproximação possa dar conta dos sentidos e repercussões dos agenciamentos daquelas mulheres.

Na sua dissertação, defendida em 2009, que, acredito, devido ao debate acendido pela Lei Antibaixaria, foi publicada cerca de três anos mais tarde (em 2012) pela EDUFBA, Nascimento admite que "não foram ouvidas, in loco, mulheres jovens provenientes da mesma camada social de onde provém o pagode para se poder saber se elas se consideram atingidas pelas letras ou se sentem representadas ou apreciadas". (Nascimento 2012b: 187).

É também preciso pensar - e essa é uma lacuna nesses estudos, que ainda são muito escassos - em como o pagode tem sido consumido por homens e mulheres pertencentes a outros estratos sociais. Pensar, por exemplo, enquanto cultura popular, as relações, influências (sobretudo) e antagonismos estabelecidos com a cultura dominante (Hall 2003 [1981]).

\section{À GUISA DE CONCLUSÃO}

Os estudos de representação sobre o pagode têm pecado por muitas vezes restringir suas abordagens à análise das letras das músicas, ou pelo menos conferindo-lhe aprioristicamente maior importância, fragmentando uma compreensão que deveria ser total: música, ritmo, dança. Dizer que a letra da música Machuca (do grupo Black Style), por exemplo, incita à violência, é ignorar o modo como se machuca - que, creio eu, será devidamente compreendido se apreciado na coreografia dessas músicas. Ou, dito de outro modo, optar por uma análise estritamente semântica da lírica implica em deixar de lado seu próprio uso e horizonte de consumo.

Interessante observar como no seu estudo sobre o funk carioca a antropóloga Mylene Mizrahi (2010) abdica da viciada proeminência da palavra nas ciências sociais para comprometer-se e dar conta do funk enquanto manifestação estético-musical. Conforme pontua:

Não se trata de afirmar que as palavras não agem ou que as letras das músicas não possuem significado nem conexão com o social e a realidade. Mas a agência do som ultrapassa a das palavras. Além disso, existe uma comunicação que só se estabelece para os iniciados, e que possui códigos em vários registros, e não somente o linguístico. (Mizrahi 2010: 183-4) 
Outro trabalho que também pode ser contrastado com a disposição assumida pelos estudos sobre o pagode é o de Marques (2013) na sua etnografia sobre o forró eletrônico no Cariri, onde, dialogicamente, imerso no campo, observa como as festas de forró inspiram e medeiam as relações afetivo-sexuais, não apenas (mas também) entre homens e mulheres.

É na sinergia entre música e sexualidade, com o som que apela incisivamente "à dança ou a outra forma de corporificação, muitas vezes sugerindo ou explicitamente referindo-se ao campo do erotismo e do sexo" (Trotta 2009: 134), que aparece a figura da mulher no pagode. Não apenas como desejada, mas como quem deseja. Algumas/alguns feministas parecem desconhecer, por conveniência ou não, o fato de que o corpo masculino é hiper-sensualizado no pagode baiano. Aliás, como mostra Cabral (1999), num dos trabalhos pioneiros sobre a temática, essa sensualidade provavelmente possibilitou a emergência de novas configurações de masculinidades heterossexuais na Bahia. Por exemplo, o heterossexual que agora está habilitado a rebolar, dançar e converter-se em objeto de desejo.

Como expus ao longo do trabalho, considero a Lei como uma resposta violenta e uma prática concreta de exclusão (Pinho 2014); tanto no que tange aos produtores quanto às/aos consumidoras/os do pagode baiano - este ritmo que invadiu feito goteira a vida social da Bahia, ainda que nela gestado. Embora os efeitos produzidos por essa verdadeira Cruzada Antipagode só possa ser avaliado ao longo dos anos vindouros, indício da violenta resposta já tem sido evidenciado, por exemplo, a partir da dita "cultura do estupro", fruto de toda uma operação de desgaste deste segmento artístico. Dito isso, defendo que a promulgação da Lei responde a certo pânico sexual e moral que o pagode provoca, portando-se desconfortavelmente como um gênero musical no limite do aceitável. 


\section{NOTAS}

1. Uma primeira versão deste trabalho foi apresentada na mesa "Quebrando a Lírica" durante a Jornada de Debates "Quebrando Tudo: Pagode, Masculinidade(s) e Racismo", que teve lugar na Faculdade de Comunicação da Universidade Federal da Bahia no dia 27 de setembro de 2012.

2. Interessante notar, já aqui precipitando um paralelo que só doravante hei de estabelecer, que "ser 'crítica' [à pornografia] sempre foi associado (...) com ser antipornografia" (Smith e Attwood 2014: 9, tradução minha).

3. Também nos Estados Unidos, de acordo com McNair (2014), pensando a pornografia como uma teoria que orienta a prática, circulara o termo rape culture, ou "cultura do estupro".

4. Sobretudo por não se tratar de uma etnografia, opto neste texto - acreditando que na sua parte final, quando me detenho nos estudos sobre o pagode, melhor se esclarecerá esta posição - em não exibir as letras das canções que cito ao longo do trabalho. Entretanto, o leitor curioso ainda poderá facilmente buscá-las no YouTube, tendo acesso a uma imensa gama de corporificações das mesmas. Neste ponto, também preferi não o direcionar para aquela que seria a coreografia por excelência da música.

5. Como não acredito ser capaz de narrar a performance de forma mais acurada, cito extensamente Rodrigues (2008:146): "a professora sobe ao palco, junto com outras mulheres, para mostrar suas habilidades de incitação erótica, estimuladas pela música 'Todo Enfiado'. A situação dirigida pelo cantor estava organizada de forma que as mulheres, uma de cada vez, durante a música, mostrassem o quanto estavam dispostas e o quanto eram competentes para incitar a sensualidade do público e do próprio cantor, indicando, em uma performance coreográfica, que a calcinha estava 'toda enfiada'. Durante o refrão, a professora empinava o bumbum, realizando movimentos de subimento e agachamento, tendo sua calcinha segurada pelo cantor que a puxava para cima, aumentando a tensão erótica entre ela, o cantor e o público. Mostrava, desavergonhadamente, o seu bumbum e parte de sua genitália. Respondia a situação aumentando a intensidade dos movimentos eróticos, deixando que o cantor se sentisse à vontade para controlar a situação, e para que ele próprio demonstrasse o seu prazer diante da possibilidade de manipulação erótica do corpo da professora".

6. O vídeo pode ser acessado em: https://www.youtube.com/watch?v=71ap0A-RjLM\#t=396.

7. Uma valiosa reflexão sobre este movimento no Brasil pode ser encontrada em Gomes \& Sorj (2014)

8. Há exemplos recentes de lutas contra opressão travadas no próprio "campo da cultura". Vale pontuar, neste sentido, a resposta à música, considerada homofóbica por alguns ativistas LGBT, "Quem banca é o viado", da banda de pagode Bailão do Robyssão, por parte do Grupo Gay da Bahia (GGB), que lançou um concurso a fim de retrucar, com uma canção, à violência. A música pode ser escutada em https://soundcloud.com/ggb-bahia/mais-amor-por-favor. Mas a resposta mais ousada vem da dançarina transexual Leo Kret, ex-vereadora de Salvador, e da banda New Play, a qual, por sua vez, pode ser conferida em https://www. youtube.com/watch?v=53CxUseWEWE.

9. Para um adensamento nos meandros da Campanha Antipornografia, recomendo a leitura de Silva (2013). 


\section{REFERÊNCIAS BIBLIOGRÁFICAS}

ADELMAN, Miriam. 2011. "Por amor ou por dinheiro? Emoções, Discursos, Mercados". Contemporânea Revista de Sociologia da UFSCar 1(2): 117-38.

BAHIA. Assembleia Legislativa. 2011. “Projeto de Lei no 19.203/2011". Recuperado em 21 abril, 2013, de http:// www.al.ba.gov.br/docs/proposicoes2011/pl__19_203_2011_1.rtf.

BAHKTIN, Mikhail. 2010 [1965]. A cultura popular na Idade Média e no Renascimento: o contexto de François Rabelais. São Paulo: Hucitec.

BECKER, Howard S. 1976 [1966]. “Os Empresários Morais”. In: Uma teoria da ação coletiva. Rio de Janeiro: Zahar.

BIROLI, Flávia. 2013. “Democracia e tolerância à subordinação: livre-escolha e consentimento na teoria política feminista". Revista de Sociologia e Política 21(48): 127-42.

CABRAL, Ygayara V. 1999. "A emergência da sensualidade masculina”. In: G. R. Soares; H. F. Gomes (orgs.) Apre(e)ndendo o social: mulheres, saúde, trabalho, futebol, sensualidade, etc. Salvador: Editora da UFBA.

CALLEJO, Javier. 2001. “El interés por la recepción". In: Investigar las audiências: um análisis qualitativo. Barcelona: Paidós.

CANCLINI, Néstor García. 2006 [1995]. “O consumo serve para pensar”. In: Consumidores e cidadãos: conflitos multiculturais da globalização. Rio de Janeiro: Editora UFRJ.

CORNEJO, Giancarlo. 2011. “La guerra declarada contra el niño afeminado: una autoetnografía queer”. Íconos: Revista de Ciencias Sociales 39: 79-95.

DÖRING, Katharina. 2004. “O samba da Bahia: tradição pouco conhecida". Ictus 5: 69-92.

FOUCAULT, Michel. 1984. História da sexualidade 2: o uso dos prazeres. Rio de Janeiro: Graal.

GOMES, Carla; SORJ, Bila. 2014. "Corpo, geração e identidade: a Marcha das vadias no Brasil". Sociedade e Estado 29(2): 433-47.

GREGORI, Maria Filomena. 2003. "Relações de violência e erotismo". Cadernos Pagu 20: 87-120.

HAKIM, Catherine. 2010. "Erotic Capital”. European Sociological Review 26(5): 499-518.

HALBERSTAM, Judith. 2008 [1998]. Masculinidad femenina. Barcelona, Madrid: Egales.

HALL, Stuart. 2003 [1981]. "Notas sobre a desconstrução do 'popular'”. In: L. Sovik (org.). Da diáspora: identidades e mediações culturais. Belo Horizonte: Editora da UFMG.

LATOUR, Bruno. 2007 [2004]. “Como falar do corpo? A dimensão normativa dos estudos sobre a ciência”. In: J. A. Nunes \& R. Roque (orgs.). Objectos impuros: estudos sociais da ciência. Porto: Afrontamento.

LEME, Mônica. 2001. “'Segure o Tchan!': Identidade na 'Axé-Music' dos anos 80 e 90”. Cadernos do Colóquio 4(1): 45-52.

MAHMOOD, Saba. 2004. "The Subject of Freedom". In: The Politics of Piety: The Islamic Revival and the Feminist Subject. Princeton: Princeton University Press.

MARQUES, Roberto. 2013. "Festa, gênero e criação no cariri do forró eletrônico". Anais do $37^{\circ}$ Encontro

Anual da ANPOCS. Recuperado em 1 março, 2014, de http://portal.anpocs.org/portal/index.php?option=com_ 
docman\&task=doc_view\&gid $=8744$ \&ltemid $=429$.

MCNAIR, Brian. 2014. "Rethinking the effects paradigm in porn studies". Porn Studies 1(1-2): 161-71.

MERLEAU-PONTY, Maurice. 2006 [1945]. "O corpo como ser sexuado". In: Fenomenologia da percepção. São Paulo: Martins Fontes.

MIZRAHI, Mylene. 2010. "É o beat que dita": criatividade e a não-proeminência da palavra na estética Funk Carioca". Desigualdade \& Diversidade - Revista de Ciências Sociais da PUC-Rio 7: 175-204.

MOURA, Milton. 1996. “Esses pagodes impertinentes...: algumas reflexões sobre o sofisticado e o vulgar no âmbito da música popular em Salvador". Textos de Cultura e Comunicação 36: 53-66.

NASCIMENTO, Clebemilton. 2012a. "Entrevista a Lorena Reis". Coluna Espaço do autor. EDUFBA. Recuperado em 21 agosto, 2012, de http://www.edufba.ufba.br/2012/08/clebemilton-nascimento/.

2012b. Pagodes baianos: entrelaçando sons, corpos e letras. Salvador: EDUFBA.

NUSSBAUM, Martha C. 1995. “Objectification”. Philosophy and Public Affairs 24(4): 249-291.

OGIEN, Ruwen. 2005. Pensar la pornografía. Barcelona: Paidós.

PENA, Anderson dos Anjos P. 2010. Cultura de consumo e relação de gênero no pagode baiano. Dissertação de Mestrado. Santo Antônio de Jesus: Universidade do Estado da Bahia.

PINHO, Osmundo. 2014. “The Black Male Body and Sex Wars in Brazil”. In: E. S. Lewis; R. Borba; B. F. Fabrício; D. S. Pinto (orgs.). Queering Paradigms IV: South-North Dialogues on Queer Epistemologies, Embodiments and Activisms. Oxford, Bern, Berlin, Bruxelle: Peter Lang.

RODRIGUES, Fernando de Jesus. 2008. “Música, vulgaridade e dinheiro: o sentido erótico-dançante nos mercados culturais das periferias urbanas". Latitude 2(2): 143-81.

RUBIN, Gayle. 1984. "Thinking Sex: Notes for a Radical Theory of Politics of Sexuality”. In: C. S. Vance (org.). Pleasure and Danger: exploring female sexuality. Boston, London, Melbourne, Henley: Routledge and Kegan Paul.

SABSAY, Leticia. 2014. "Des-heterossexualizar a cidadania é ainda uma frente de batalha". Revista Cult 193: 38-41.

SARDENBERG, Cecilia M. B. 2011. "A violência simbólica de gênero e a Lei 'Antibaixaria' na Bahia". OBSERVE - Observatório de Monitoramento da Lei Maria da Penha. Recuperado em 25 março, 2014, de http://www. observe.ufba.br/debate.

SILVA, Júlio César C. B. 2013. “Liberdade de expressão, pornografia e igualdade de gênero". Estudos Feministas 21(1): 143-165.

SMITH, Clarissa; ATTWOOD, Feona. 2014. “Anti/pro/critical porn studies". Porn Studies 1(1-2): 7-23.

SOUTO, Jane. 1997. “Os outros lados do Funk Carioca”. In: H. Vianna (org.). Galeras cariocas: territórios de conflitos e encontros culturais. Rio de Janeiro: Editora da UFRJ.

SOVIK, Liv. 2009. Aqui ninguém é branco. Rio de Janeiro: Aeroplano.

SPIVAK, Gayatri Chakravorty. 2010 [1988]. Pode o subalterno falar? Belo Horizonte: Editora da UFMG.

TINHORÃO, José Ramos. 1972. “Música e danças de negros e mestiços”. In: Música popular de índios, negros e mestiços. Petrópolis: Vozes. 
2008. "A razão das umbigadas: o lundu, a fofa e o fado nos séculos XVIII e XIX". In: Os sons dos negros no Brasil: cantos, danças, folguedos: origens. São Paulo: Ed. 34.

TROTTA, Felipe. 2009. "Música popular, moral e sexualidade: reflexões sobre o forró contemporâneo". Contracampo 20: 132-146.

VIANNA, Hermano. 1997. O mundo funk carioca. Rio de Janeiro: Jorge Zahar. 


\section{Pagode e perigo: rediscutindo contendas de gênero na Bahia}

\section{RESUMO}

Este artigo é fruto do esforço de apresentar uma crítica sistemática à Lei Antibaixaria, aprovada pela Assembleia Legislativa do Estado da Bahia em 2012. Para isso, primeiramente contextualizo o cenário, enredado pelo pagode, em que fora travada uma disputa político-ideológica acerca da representação da mulher. Em seguida, examino de modo minucioso alguns dos pressupostos que fundamentaram a Lei Antibaixaria, observando a relação destes com aqueles que embasaram o movimento antipornografia, iniciado nos EUA dos anos 70. Já na última parte do texto, realizo uma breve ponderação acerca de estudos que têm sido realizados sobre o pagode baiano e as relações de gênero nele tecidas, apontando suas principais limitações.

PALAVRAS-CHAVE: Música; Feminismo; Relações de gênero.

\section{Pagode and danger: rethinking gender controversy in Bahia}

\section{ABSTRACT}

This article aims at presenting a systematic critique of the so-called Antibaixaria bill of law, passed in 2012 by the Legislative Assembly of the State of Bahia. In order to do so, firstly I contextualize the case of pagode in relation to the political/ideological controversy regarding the representation of women. Secondly, I examine some of the assumptions that grounded the Antibaixaria bill, relating them to the anti-pornography movement initiated in the 70's in the USA. Finally, I present a brief review of recently published studies on Bahia's pagode and gender issues, pointing out some of their main limitations.

KEYWORDS: Music; Feminism; Gender relations. 